\title{
Restaurant proactive philanthropic activities and customer loyalty: a scenario-based study during the COVID-19 pandemic period
}

\author{
Li Ding \\ Institut Paul Bocuse, Ecully, France, and \\ Caifen Jiang \\ Guangzhou University, Guangzhou, China
}

\begin{abstract}
Purpose - This study aims to (1) examine the effect of customer awareness of restaurant philanthropic activities on customer loyalty; (2) investigate the mediating roles of customer social benevolence trust, perceived restaurant reputation and affective commitment on the relationship between their awareness of restaurant philanthropic activities and customer loyalty; and (3) test the path effect differences between the directed and general philanthropic activities during the COVID-19 pandemic period.

Design/methodology/approach - This study used online scenario-based surveys to collect data. Based on 293 useable surveys, partial least squares structural equation modeling was applied for data analysis.

Findings - This study finds that customer awareness of restaurant philanthropic activities positively relates to customer loyalty. Moreover, customer social benevolence trust, perceived restaurant reputation and affective commitment have positive mediating effects on the relationship between their awareness of restaurant philanthropic activities and customer loyalty. There is no significant path effect difference between the directed and general philanthropic activities.

Practical implications - This study suggests that restaurant decision-makers should conduct either directed or general philanthropic activities as a marketing tool to sustain customers during the COVID-19 recovery.

Originality/value - This study is the first study that discusses the marketing role of corporate philanthropy in the restaurant industry during the COVID-19 pandemic and stresses the importance of proactive strategic donations that helps restaurants' recovery.
\end{abstract}

Keywords Philanthropy awareness, Customer loyalty, Social benevolence trust, Affective commitment, Corporate reputation, COVID-19, Marketing strategy, Restaurant

Paper type Research paper

\section{Introduction}

Coronavirus disease 2019 (COVID-19) has been significantly spreading into many countries in the world since the end of 2019. Based on statistics from the World Health Organization (WHO, 2020), there were 81,947,503 confirmed cases and 1,808,041 confirmed deaths worldwide by January 1, 2021. Among the 222 influenced countries, territories and areas, the

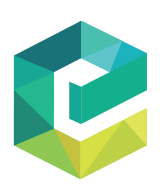

International Hospitality Review Vol. 35 No. 2, 2021 pp. $260-279$ Emerald Publishing Limited 2516-8142 DOI 10.1108/IHR-08-2020-0045
(C) Li Ding and Caifen Jiang. Published in International Hospitality Review. Published by Emerald Publishing Limited. This article is published under the Creative Commons Attribution (CC BY 4.0) licence. Anyone may reproduce, distribute, translate and create derivative works of this article (for both commercial and non-commercial purposes), subject to full attribution to the original publication and authors. The full terms of this licence may be seen at http://creativecommons.org/licences/by/4.0/ legalcode

The authors would like to thank Dr. Hailin Qu's comments and suggestions on this study and thank the reviewers and editor for their thoughtful comments toward improving our manuscript. Dr. Hailin Qu is the Regents Professor Emeritus and William E. Davis Distinguished Chair Emeritus at Oklahoma State University. 
USA was top ranked with 19,663,976 cumulative confirmed cases and 341,199 cumulative confirmed deaths by December 31, 2020 (CDC, 2020). For securing public health, a large portion of the world population had been quarantined at home and worked remotely. International and domestic travels were restricted, and non-essential businesses were closed to comply with government regulations. On March 13, 2020, the USA declared a national state of emergency. The low population mobility raised the unemployment rate and significantly hit the economy. The peak unemployment rate of above $14 \%$ occurred in April 2020 (DOL, 2020). The recovery has been appearing under the new normal situation since June 2020. Although communities and businesses are reopening, many businesses filed for bankruptcy, such as NPC International Inc. (the largest franchisee of Pizza Hut restaurants) and CEC Entertainment (the parent company of Chuck E. Cheese) (Clifford et al., 2020).

No doubt, the COVID-19 pandemic significantly hit the hospitality and tourism industry, and the impacts may last in the long-run. Because of the travel restrictions and public health precautions, flights and leisure/business travel were canceled and many hotels were temporarily shut down (Smart et al., 2021). Restaurant businesses have suffered from an extremely difficult time as well. Based on statistics from the National Restaurant Association (2020), the industry sales of US\$32.4bn (inflation-adjusted) in April 2020 reached the lowest point since October 1984. As most restaurants temporarily closed to reduce the spread of COVID-19, the industry was facing a crisis of null operating income, heavy costs that had to be paid and the layoff of employees. The business relationship between the customers and the restaurants almost stopped because the customers were unable to experience onsite restaurant food and services. After the lockdown, the number of dine-out customers may decrease compared with the pre-COVID-19 period because of the perceived risk, reduced disposable income and switching to a newly cultivated home-cooking style. Therefore, the restaurant industry's challenge has been extended from the confinement period to the recovery period.

During the COVID-19 pandemic, the normal operations of many restaurants were affected by government regulations and significantly reduced customer volume. However, many of them utilized the available resources to conduct some philanthropic activities during this difficult time. For example, more than 30 restaurants around the country gave back to their communities with free meals and groceries (Nierenberg, 2020). Local restaurants and big chains gave free meals to frontline workers and first responders (Maze, 2020). Corporate philanthropy has been used as a marketing strategy to enhance a firm's favorable image and reputation for a long time. Our interest targets the question, can these proactive corporate philanthropic activities strengthen customer loyalty and help the restaurant business recovery during the post-COVID-19 pandemic period?

Therefore, this study aims to (1) examine the effect of customer awareness of restaurant philanthropic activities on customer loyalty; (2) investigate the mediating roles of customer social benevolence trust, perceived restaurant reputation and affective commitment on the relationship between their awareness of restaurant philanthropic activities and customer loyalty; and (3) test the path effect differences between the directed and general philanthropic activities during the COVID-19 pandemic period.

There is a significant lack of empirical discussion regarding the impact of corporate philanthropy on key stakeholders (e.g. customers) in the hospitality field (Wang et al., 2019). Theoretically, this study explored the important role of corporate philanthropy as a marketing tool to build customer loyalty in the restaurant industry. The study specified the unique characteristics of corporate philanthropy and distinguished corporate philanthropic activities from other corporate social responsibility (CSR) dimensions. The proposed model emphasized the importance of restaurant philanthropic activities on sustaining customer loyalty during the COVID-19 pandemic period. This study used the scenario-based method to reach two different types of restaurant philanthropic activities 
IHR

35,2

and found that both types reflected the restaurant's proactive marketing efforts to enhance its business image and build strong brand associations with the customers during the COVID-19 pandemic period. Practically, this study generated implications for the restaurant operators under the COVID-19 pandemic period. The study suggested that the current priority of the restaurants was to retain customers and attract customers back to the businesses. Therefore, investing in efficient marketing tools, such as corporate philanthropic activities, is important to reach this goal.

\section{Literature review}

\subsection{Corporate philanthropy and customer awareness of corporate philanthropic activities}

Strategic corporate philanthropy refers to "a discretionary responsibility of a firm involving choosing how it will voluntarily allocate resources to charitable or social service activities in order to reach marketing and other business related objectives for which there are no clear social expectations as to how the firm should perform" (Ricks, 2005, p. 122). It is classified into four types: proactive-directed, proactive-general, reactive-directed and reactive-general (Ricks, 2005). Among them, the proactive corporate philanthropic activities during the COVID-19 pandemic are our study focus. Proactive-directed philanthropy refers to "philanthropic activity that is designed to increase visibility or enhance corporate image and is not in response to an event that pressures the company to respond, and that does benefit a particular segment that the company is likely to target for business or wants to associate with for strategic reasons" (Ricks, 2005, p. 123). Proactive-general philanthropy refers to "philanthropy activity that is designed to increase visibility or enhance corporate image and is not in response to an event that pressures the company to respond, and that does not benefit a particular segment that the company is likely to target for business or wants to associate with for strategic reasons" (Ricks, 2005, p. 123). Corporate philanthropy differs from the concept of CSR. CSR has a broader domain, which accesses any organizational actions that aim to achieve social benefits and maximize shareholders' profits and fulfill legal obligations (Carroll and Shabana, 2010). As a multi-dimensional concept, CSR has been discussed from many perspectives, such as environment, community and employee relations (Ding et al., 2018). Corporate philanthropy closely associates with community CSR.

The motive of firms conducting philanthropic activities is debatable. Although altruism could be one of the rationales for corporate philanthropy, profit-driven considerations could be a primary motive as well (Fry et al., 1982). Many firms involved in philanthropic activities strive to create a socially responsible public image to build positive moral capital among communities and eventually expect to maximize economic benefits (Godfrey, 2005). However, previous literature found mixed results toward the effect of corporate philanthropy on a firm's financial performance (Wang et al., 2008), mainly because charity donations might not use a firm's resource efficiently and not directly benefit shareholders in the short run (Friedman, 1970; Wang et al., 2008).

Rather than focusing on the firm's financial performance, the intangible benefits brought by philanthropic activities have drawn researchers' increasing attention (Lim, 2010; Peterson, 2018). Corporate philanthropy has been used as a tool to enhance firm visibility in causerelated marketing (Porter and Kramer, 2002). It can help improve customer-perceived corporate reputation (Peterson, 2018; Szőcs et al., 2016). However, the number of studies in the hospitality industry is limited (Wang et al., 2019). Lee et al. (2014) investigated the positive impact of corporate philanthropy on Korean hotel employee engagement and turnover intention. Wang et al. (2019) used the game theory method to explain how hospitality corporate philanthropy influences customer benefits and proposed a theoretical model. There is a significant lack of empirical discussion regarding the impact of corporate philanthropy on customers in the hospitality field. As we previously mentioned, many restaurants donated 
free food and groceries to the local communities during the COVID-19 pandemic. The impact of these philanthropic activities on the restaurant operations from the customer perspective should be further investigated.

Servaes and Tamayo (2013, p. 1045) argued that "a necessary condition for CSR to modify consumer behavior and, hence, affect firm value, is consumer awareness of firm CSR activities." Accordingly, Walker and Kent (2013) introduced the concept of customer awareness of corporate philanthropic activities when they discussed the relationship between corporate philanthropy and consumer behavior. Customer awareness relates to their evaluations of products and services (Cronin et al., 2000; Walker and Kent, 2013). Being aware of the firm's activities is important to developing beliefs regarding the firm (Brown et al., 2006). The customers can be aware of and evaluate the firm's philanthropic efforts through communications.

\subsection{Customer awareness of corporate philanthropic activities and social benevolence trust}

Customer trust is the "trust customers have toward a firm, is formed based on prior experience with a firm" (Choi and La, 2013, p. 224). Social benevolence trust is "consumers' belief that a company is genuinely concerned with the preservation and enhancement of the welfare of society" (Park et al., 2014, p. 297). Based on the social identity theory (Ashforth and Mael, 1989; Tajfel and Turner, 1985), people can use a social identity to reinforce their selfconcept. Because corporate philanthropic activities can generate prestige- and respect-based identification (Jalilvand et al., 2017), customers tend to trust such firms that meet their expectations and have a prestigious image (Glavas and Godwin, 2013). Although customers may not directly gain benefits from the firm's philanthropy, they expect that the firms are willing to allocate financial and non-financial resources to contribute to the well-being of society (Park et al., 2014). Therefore, the customers will have social benevolence trust toward the firms. H1 was developed as:

H1. Customer awareness of corporate philanthropic activities positively relates to customer social benevolence trust.

\subsection{Customer awareness of corporate philanthropic activities and customer-perceived corporate reputation}

Corporate reputation represents the stakeholders' overall assessments and accumulated perceptions of the firm's past performance and how well the firm meets their expectations (Abratt and Kleyn, 2012; Barnett et al., 2006). The corporate reputation relates to the firm's credibility (Casalo et al., 2007). The customers will psychologically generate positive associations to the firm with a good reputation (Dowling, 2006). There is a tight link between corporate philanthropy and customer-perceived corporate reputation. Bramner and Millington (2005) found that firms with higher philanthropic spending were evaluated as being high in social responsibility and reputation. Peterson (2018) investigated the positive relationship between corporate philanthropy and corporate reputation for the firms with an existing good reputation. Therefore, $\mathrm{H} 2$ was developed as:

H2. Customer awareness of corporate philanthropic activities positively relates to customer-perceived corporate reputation.

The direction of the relationship between customer social benevolence trust and perceived corporate reputation is debatable (Park et al., 2014). Keh and Xie (2009) found a positive relationship between corporate reputation and customer trust and concluded that corporate reputation was the antecedent of customer trust. A similar conclusion can be found in the study of Kim and Kim (2016). Park et al. (2014) argued the opposite causal direction, that high 
IHR

35,2

customer trust led to a high corporate reputation based on the framework of belief, attitude, intention and behavior. Following this argumentation, H3 was developed as:

H3. Customer social benevolence trust positively relates to customer-perceived corporate reputation.

\subsection{Customer affective commitment}

Customer commitment is "a psychological link between customers and an organization that enables the former to maintain a valued relationship" (Hur et al., 2018, p. 1261). There are three types of commitment: normative, continuance and affective (Bansal et al., 2004). Among them, affective commitment refers to "affective or emotional attachment to the organization such that the strongly committed individual identifies with, is involved in, and enjoys membership in the organization" (Allen and Meyer, 1990, p. 2). It is an emotional response that roots customers' psychological identification and attachment to the firm (Fullerton, 2003). The CSR activities help generate customer-perceived corporate reputation that links to their emotions toward the firm (Bartikowski and Walsh, 2011). Markovic et al. (2018) found that customerperceived ethicality enhanced their affective commitment. Thus, H4 was developed as:

H4. Customer awareness of corporate philanthropic activities positively relates to customer affective commitment.

In a marketing context, trust is a critical factor in developing an effective customer-firm relationship (Morgan and Hunt, 1994). Customer trust has been found as an antecedent of customer affective commitment (Fullerton, 2011). When customers perceive the firm's high creditability, they may feel emotionally attached to this firm in the long run and therefore generate affective commitment (Morgan and Hunt, 1994). Thus, H5 was developed as:

H5. Customer social benevolence trust positively relates to customer affective commitment.

Similarly, the customer-perceived corporate reputation can be considered the antecedent of customer affective commitment (Gözükara and Yildirim, 2015). Based on the social identity theory (Tajfel and Turner, 1985), customers may have the identity sense from the affiliated groups. The high customer-perceived corporate reputation reflects higher evaluations by others. Accordingly, customer affective commitment is higher. Customers tend to emotionally attach to that firm. A firm with a favorable reputation may develop a strong emotional attachment from the customers and create customer affective commitment in the long run. The positive relationship between corporate reputation and affective commitment can be found in previous studies (Alniacik et al., 2011). Thus, H6 was developed as:

H6. Customer-perceived corporate reputation positively relates to customer affective commitment.

\subsection{Customer loyalty}

Brand loyalty reflects how the customers emotionally attach to a brand (Aaker, 1991). The loyal customers may repurchase the products or services, spread positive word-of-mouth and recommend others to purchase (Gronholdt et al., 2000). The level of loyalty is closely related to customer repurchase intentions (Kim et al., 2007).

Customers' benevolence trust reflects their reliance upon the concern offered by the firm. Martinez and Bosque (2013) mentioned that hotel customers' benevolence trust indicated their belief that the hotel would not only act with economic purpose but also showed their care about customer well-being through the products and services. In addition, following the framework of Fishbein and Ajzen (1975), the customer-perceived corporate reputation and 
affective commitment reflect their belief and attitude toward the firm and will lead to their behavioral intentions, such as repurchase intentions and word-of-mouth. Therefore, we developed $\mathrm{H} 7, \mathrm{H} 8$ and $\mathrm{H} 9$ as:

H7. Customer social benevolence trust positively relates to customer loyalty.

H8. Customer affective commitment positively relates to customer loyalty.

H9. Customer-perceived corporate reputation positively relates to customer loyalty.

Therefore, Figure 1 presents the conceptual framework of this study.

\section{Methods}

\subsection{Research design}

This study used scenarios to demonstrate restaurant corporate philanthropic activities. Restaurant corporate philanthropy was manipulated by two philanthropic activities. With the control groups and considering two types of population groups, six versions of survey questionnaires were designed. Each version included a new scenario. Table 1 presented classifications of six versions of the survey.

The "target population" in the scenarios refers to the imagined residents in a hypothetical city who were in a food-insecure situation. The food-insecure situation in this study means the situation with worries about food shortage or food susceptible to virus contamination. The "non-target population" in the scenarios refers to the imagined residents in this city who were not in a food-insecure situation. When we delivered the questionnaires to the participants, differentiating the conditions of the target population and the non-target population was better for the survey participants imagining and positioning their perceptions into the given population groups. However, as this study aimed to investigate the general marketing effects of proactive corporate philanthropic activities and find effective ways to attract customers on a broad scale, we did not focus on discussing their effect differences in target and non-target population groups. Therefore, the target and non-target group data were later merged and condensed into three groups: directed philanthropic group, general philanthropic group and control group.

\subsection{Stimulus materials}

The scenarios were developed as the stimulus. All scenarios used the same fictitious restaurant name, Delicious, and stated description of the restaurant and its philanthropic activities during the COVID-19 pandemic period. The restaurant description was stated as:

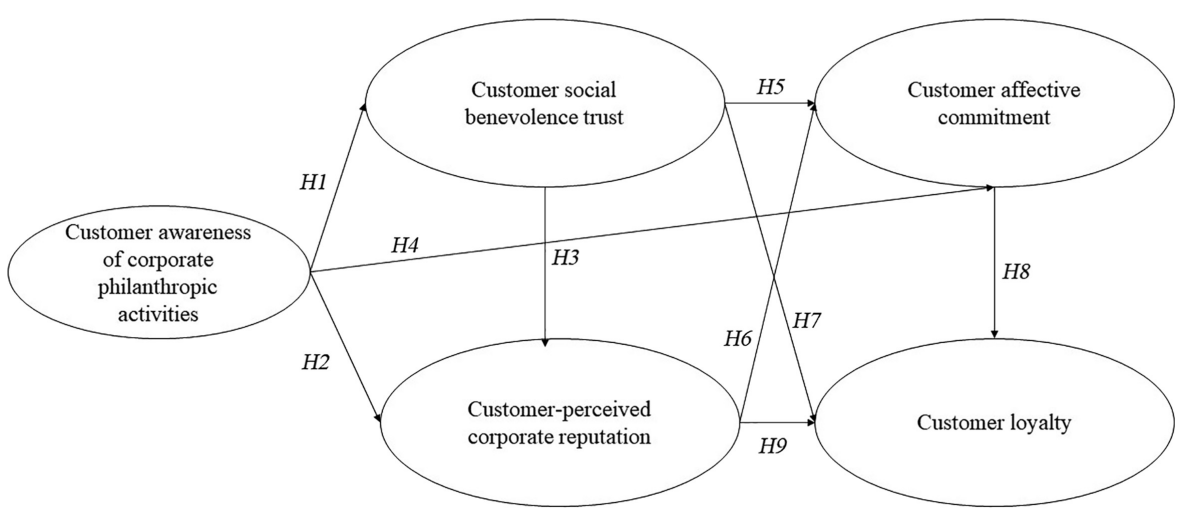

Figure 1.

Proposed conceptual framework 


\begin{tabular}{|c|c|c|c|c|c|c|}
\hline $\begin{array}{l}\text { IHR } \\
35,2\end{array}$ & $\begin{array}{l}\text { Survey } \\
\text { version }\end{array}$ & Scenario & Group & $\begin{array}{l}\text { Number of } \\
\text { surveys } \\
\text { distributed }\end{array}$ & $\begin{array}{l}\text { Number of } \\
\text { surveys } \\
\text { useable }\end{array}$ & $\begin{array}{l}\text { Response } \\
\text { rate }\end{array}$ \\
\hline \multirow{4}{*}{266} & v1 & $\begin{array}{l}\text { Directed philanthropic } \\
\text { activity toward the target } \\
\text { population }\end{array}$ & Treatment & 100 & 53 & $53 \%$ \\
\hline & v2 & $\begin{array}{l}\text { Directed philanthropic } \\
\text { activity toward non-target } \\
\text { population }\end{array}$ & Treatment & 100 & 63 & $63 \%$ \\
\hline & v3 & $\begin{array}{l}\text { General philanthropic } \\
\text { activity toward the target } \\
\text { population }\end{array}$ & Treatment & 100 & 57 & $57 \%$ \\
\hline & v4 & $\begin{array}{l}\text { General philanthropic } \\
\text { activity toward non-target } \\
\text { population }\end{array}$ & Treatment & 100 & 59 & $59 \%$ \\
\hline $\begin{array}{l}\text { Table } 1 . \\
\text { Classifications of six }\end{array}$ & v5 & $\begin{array}{l}\text { No philanthropic activity } \\
\text { toward target population }\end{array}$ & Control & 100 & 33 & $33 \%$ \\
\hline $\begin{array}{l}\text { versions of survey } \\
\text { questionnaires and } \\
\text { response rates }\end{array}$ & v6 & $\begin{array}{l}\text { No philanthropic activity } \\
\text { toward non-target } \\
\text { population }\end{array}$ & Control & 100 & 28 & $28 \%$ \\
\hline
\end{tabular}

Delicious, a local Mediterranean bistro restaurant, was founded by Nick Davis and Tom Hughes in City of Amazing in 2010. Nick and Tom met more than 2 decades ago as cooks in some of the most acclaimed kitchens in Paris. They spent late nights after work recounting adventures in travel and food, and how they could bring the two together in their own place one day. Delicious was born from these wandering conversations. The restaurant serves healthy and delicious food every day. Delicious is located in the downtown of the city; it has 50 seats maximum and an option for takeaway. The restaurant uses a big part of the first floor as a dining room, as well as a terrace. The main course options include Vegetarian Casserole, Fish of the Day, and Lamb Stew with Herbs. Besides, Starters, such as Vegetable Tagine, Mediterranean Beans Salad, and Seasonal Chakshuka are also provided. The restaurant also serves plenty of tasty desserts and appetizers. The average check price is about $\$ 25$ for lunch and dinner. The average rating score from online reviewers is above the moderate level. There is no loyalty program in this restaurant. The restaurant did not have a previous philanthropy record.

The directed philanthropic activity was described as, "During the COVID-19 pandemic period, Restaurant Delicious is working with its chefs, cooks, wait staff, and local farmers to produce, donate, and deliver thousands of dollars' worth of free food (a value of $\$ 50,000$ ) to the residents in the local community who are experiencing a food-insecure situation during the COVID-19 pandemic." The general philanthropic activity was described as, "During the COVID-19 pandemic period, Restaurant Delicious donated $\$ 50,000$ to a non-profit organization, the Healthy Dining Institution." The control groups were only provided the basic restaurant description without any philanthropic activity information. In addition, the experiment design separated the target population and the non-target population and merged these two population groups for further data analysis.

\subsection{Sampling and data collection}

A self-selected convenience sampling method was applied to draw the sample. Data were collected from the online survey on Amazon Mechanical Turk (MTurk), an online crowdsourcing platform, to generate reliable and diverse data samples (Behrend et al., 2011). Each participant could only respond to one of the six survey versions. Based on the conceptual model, and setting up the parameters on the software G*Power3 (medium 
effect size as 0.15 , a significant level of 0.05 and the power as 0.80 ), we obtained $a$ priori minimum sample size of 55 for using the partial least squares-structural equation modeling (PLS-SEM) method. To draw online survey participants' attention and enhance the response rate and speed, monetary incentives were offered based on the successful submission of the survey (Ali et al., 2020). Based on the financial budget, 100 submitted surveys for each scenario were accepted and incentives were paid online (600 surveys in total). After removing the incomplete surveys and ruling out those respondents who provided wrong answers to two manipulation questions, 293 respondents were retained for further analysis, including 116 in the directed philanthropic group, 116 in the general philanthropic group and 61 in the control group. The overall response rate is $48.83 \%$. Table 1 also shows the response rate for each scenario. The response rate is within the acceptable range by considering other empirical hospitality literature summarized by Ali et al. (2020). The control group would be only used for mean comparison rather than PLS-SEM analysis.

\subsection{Measures and data analysis}

Survey respondents selected their opinions from multi-item seven-point Likert-scale measures from "strongly disagree" (1) to "strongly agree" (7). Customer awareness of corporate philanthropic activities was measured by three items adapted from Walker and Kent (2013). Customer social benevolence trust was measured by six items adapted from Xie and Peng (2011). Customer-perceived corporate reputation was measured by three items from Hur et al. (2014). Customer affective commitment was measured by three items from Iglesias et al. (2019). Customer loyalty was measured by five items adapted from Mattila (2006) and Namkung and Jang (2007). A pilot test with a sample size of 30 participants on MTurk was conducted, and the Cronbach's $\alpha$ of each construct was above 0.70, indicating an acceptable internal consistency.

Because common method variance (CMV) is a common problem in survey-based behavioral research, it is necessary to stress the CMV issue in this study. CMV is defined as "variance that is attributable to the systematic measurement error rather than study constructs that the measures represent" (Min et al., 2016, p. 126). The significant CMV may be deleterious to estimate the relationships of constructs by distorting the correlations of these variables (MacKenzie and Podsakoff, 2012; Podsakoff et al., 2003, 2012). Min et al. (2016) summarized four CMV sources, which were common effects, item characteristic and context effects, measurement context effects and individual differences (MacKenzie and Podsakoff, 2012; Podsakoff et al., 2003). Recommended procedural remedies and/or statistical controls may be chosen to stress the CMV issues during data analysis (Min et al., 2016). Because this study collected the customers' perceptions' data from the online platform MTurk through a scenario-based research design, it limited the ability to use ex ante procedural remedies to reduce the CMV. However, the unmeasured latent method factor statistical control was used to assess if the CMV was in the acceptable range (Min et al., 2016; Podsakoff et al., 2003). This study compared all indicators' factor loadings' difference between the measurement model without adding an unmeasured latent variable and the measurement model with an unmeasured latent variable. A $t$-test was used to exam if the differences were significant. The result $(t=0.47 . p=0.64)$ failed to find the significant difference, which meant the CMV caused by an unmeasured latent variable did not significantly distort all other indicators' factor loadings in the measurement model. As the unmeasured latent method factor has been found as an effective approach of statistical control (Min et al., 2016), it indicated that the CMV was not a significant issue in this study.

PLS-SEM was used to align with research purposes and effectively explore the hypothesized path relationships (Hair et al., 2017). Differing from the covariance-based SEM 
IHR

35,2

\section{8}

(CB-SEM) that uses maximum likelihood estimation method to "reproduce the covariance matrix [i.e. minimizing the difference between the observed and estimated covariance matrix], without focusing on explained variance" (Hair et al., 2011, p. 139), PLS-SEM "applies ordinary least squares (OLS) regression with the objective of minimizing the error terms (i.e. the residual variance) of the endogenous constructs" and "estimates coefficients (i.e. path model relationships) that maximize the $R^{2}$ values of the (target) endogenous constructs" (Hair et al., 2017). PLS-SEM has been found empirically useful and having relatively higher advantages to process the data analysis based on the models with complex relationships in hospitality and tourism fields (Ali et al., 2018). This study assesses the effects of customer awareness of restaurant philanthropic activities on customer loyalty in the restaurant industry, which is an innovatively stressed relationship without significant focuses on previous theories. Therefore, using PLS-SEM fits this theory development perspective (Ali et al., 2018). Moreover, because the sample size is relatively small to conduct CB-SEM for the directed philanthropic group $(n=116)$ and general philanthropic group $(n=116)$, PLS-SEM has a relative advantage to process the small sample size (Ali et al., 2018). In addition, using PLS-SEM may generate higher item loadings and strengthen the reliability and validity of the model, as well as retain more reliable items for this study.

To test the significance of the hypothesized path effects, bootstrap analysis was performed to provide robust evidence. SmartPLS 3.2 software was used for data analysis. Although applying PLS-SEM generally does not require any data distribution assumptions (Hair et al., 2017), this study still accessed the data normality by skewness and kurtosis, which were two measures recommended by Hair et al. (2017). All indicators' skewness and kurtosis values were within the -1 and +1 acceptable range (Hair et al., 2017), except for the slightly large values from the item cp3 (skewness $=-1.146$ ) and item ac3 (skewness $=-1.049$, kurtosis $=1.491$ ). Item ac3 was deleted because of the low outer loading.

\section{Results}

\subsection{Characteristics of respondents}

The sample of 293 respondents can be characterized as follows: 171 male (58.4\%) and 122 female (41.6\%), $5.1 \%$ were between 19 and 24 years old, $47.1 \%$ between 25 and 34 years old, $21.5 \%$ between 35 and 44 years old, $15.0 \%$ between 45 and 54 years old, $6.2 \%$ between 55 and 64 years old and $5.1 \%$ over 65 years old, inclusive. College-educated respondents accounted for $66.6 \%$ of the sample. Also, $19.1 \%$ had post-college graduate degrees, followed by some college experience $(10.6 \%)$ or high-school education $(2.0 \%)$.

\subsection{Independent sample t-test between groups}

We used the independent sample $t$-test to investigate the mean difference for each construct between the treatment and control group. Table 2 shows a summary of the test. We find that the customer awareness of restaurant-directed philanthropic activities is higher than the control group $(t=14.023, p<0.05)$ and higher than the customer awareness of restaurant general philanthropic activities $(t=5.147, p<0.05)$. Customer awareness of restaurant general philanthropic activities is greater than the control group $(t=10.484, p<0.05)$. Similar $t$-test results can be found from the mean values of other constructs.

\subsection{Measurement model}

PLS-SEM is used to maximize the explained variance of the endogenous latent variables in the PLS path model (Hair et al., 2017). In the proposed conceptual model, the constructs of customer awareness of corporate philanthropic activities, customer social benevolence trust, customer-perceived corporate reputation, customer affective commitment and customer 


\begin{tabular}{|c|c|c|c|c|c|c|c|c|c|c|}
\hline $\begin{array}{l}\text { Mean of the } \\
\text { construct }\end{array}$ & Mean & Directe & $\begin{array}{l}d \text { philanthro } \\
t \text { value, } \\
\text { compared } \\
\text { with the } \\
\text { control } \\
\text { group }\end{array}$ & $\begin{array}{l}\text { group } \\
t \text { value, } \\
\text { compared } \\
\text { with general } \\
\text { philanthropy } \\
\text { group }\end{array}$ & Gen & $\begin{array}{r}\text { eral ph } \\
\text { gro }\end{array}$ & $\begin{array}{l}\text { anthropic } \\
\mathrm{p} \\
t \text { value, } \\
\text { compared } \\
\text { with the } \\
\text { control } \\
\text { group }\end{array}$ & 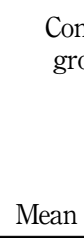 & $\begin{array}{l}\text { rol } \\
\text { up }\end{array}$ & $\begin{array}{r}\text { Restaurant } \\
\text { proactive } \\
\text { philanthropic } \\
\text { activities }\end{array}$ \\
\hline $\begin{array}{l}\text { Customer } \\
\text { awareness of } \\
\text { corporate } \\
\text { philanthropic } \\
\text { activities }\end{array}$ & 5.71 & 0.85 & $14.023^{*}$ & $5.147^{*}$ & 5.12 & 0.89 & $10.484^{*}$ & 3.31 & 1.18 & \\
\hline $\begin{array}{l}\text { Customer } \\
\text { social } \\
\text { benevolence } \\
\text { trust }\end{array}$ & 5.90 & 0.51 & $9.640^{*}$ & $9.122^{*}$ & 5.17 & 0.69 & $3.447^{*}$ & 4.77 & 0.84 & \\
\hline $\begin{array}{l}\text { Customer- } \\
\text { perceived } \\
\text { corporate } \\
\text { reputation }\end{array}$ & 5.97 & 0.59 & $10.403^{*}$ & $7.848^{*}$ & 5.25 & 0.80 & $4.182^{*}$ & 4.71 & 0.84 & \\
\hline $\begin{array}{l}\text { Customer } \\
\text { affective } \\
\text { commitment }\end{array}$ & 5.95 & 0.55 & $8.998^{*}$ & $8.263^{*}$ & 5.20 & 0.81 & $3.721^{*}$ & 4.61 & 1.09 & \\
\hline $\begin{array}{l}\text { Customer } \\
\text { loyalty }\end{array}$ & 5.91 & 0.60 & $8.697^{*}$ & $9.006^{*}$ & 5.09 & 0.78 & $2.631^{*}$ & 4.73 & 0.96 & $\begin{array}{r}\text { Table } 2 . \\
\text { Independent sample }\end{array}$ \\
\hline Note(s): *sig a & 0.05 , tw & o-tailed & & & & & & & & $t$-test results summary \\
\hline
\end{tabular}

loyalty were measured by the reflective indicators. The key important PLS-SEM measurement model metrics are reliability, convergent validity and discriminant validity (Hair et al., 2017). For the measurement and structural model assessment and estimation, we excluded the control group and focused on two treatment groups only.

Using the PLS algorithm to run PLS-SEM, we accessed construct reliability and convergent validity of the reflective measurement model. The outer loading of each indicator represents indicator reliability that is an efficient way to evaluate the convergent validity of the measurement model. Two items with low outer loading values were eliminated to improve the average variance extracted (AVE). From Table 3, we found that all items had outer loadings above the rule of thumb 0.70 (Hair et al., 2017), except for three items with values that were very close to 0.70 . The values of the AVE that assessed the convergent validity on the construct level were all above the cut-off level of 0.50 , indicating a good convergent validity in the measurement model. The model's internal consistency reliability was assessed by the values of composite reliability (CR) for all constructs. From Table 3 , we found that the values of $\mathrm{CR}$ for all constructs were above 0.80 , indicating satisfactory internal consistency reliability without considerable redundant items.

We checked the cross-loadings of each construct and found that each indicator's outer loading on the related construct was above its cross-loadings on other constructs (Hair et al., 2017). It indicated good discriminant validity. Harman's single-factor test was further conducted for all items of the five constructs in the measurement model to assess the CMV issue. The total variance explained for a single factor was $40.482 \%$, which was less than $50 \%$. Although Harman's single-factor test signals the CMV possibility rather than controlling the CMV (Min et al., 2016), the test result indicates that the signal of CMV possibility is in an acceptable range (Podsakoff et al., 2003). 
\begin{tabular}{lr} 
Construct & Oute \\
\hline
\end{tabular}

Outer
ading

Customer awareness of corporate philanthropic activities

\section{0}

Customer social benevolence trust

Customer-perceived corporate reputation

Customer affective commitment

Customer loyalty

Table 3.

Deleted items

Summary of measurement model $\mathrm{cp} 2$ : The restaurant is s charitable business

cp3: I am aware of the philanthropic activities of the restaurant

tr2: I rely on the restaurant to favor the customer's best interest tr3: If the food or services have problems in this restaurant, I am confident that the restaurant would respond constructively and caringly tr4: I believe that this restaurant has a great deal of benevolence

tr5: This restaurant acts as if they value you as a customer

tr6: When making important decisions, this restaurant considers our welfare as well as its own

rp1: The restaurant is a company I have a good feeling about

rp2: The restaurant is a company that I admire and respect

rp3: The restaurant has a good overall reputation

acl: I enjoy being a customer of this restaurant ac2: I have positive feelings about this restaurant

ly1:I say positive things about this restaurant to other people

ly2: I recommend this restaurant to someone

who seeks my advice

ly3: I encourage friends and relatives to do

business with this restaurant

ly4: I consider this restaurant your first choice when dining

ly5: I would like to come back to this restaurant in the future

tr1: This restaurant treats customers with respect

ac3: I feel attached to this restaurant brand $\mathrm{cp} 1$ : The restaurant does good things for the community $\begin{array}{lll}0.794 & 0.813 \quad 0.591\end{array}$

0.773

0.739

$0.751 \quad 0.843 \quad 0.517$

0.697

0.707

0.743

0.695

$0.754 \quad 0.804 \quad 0.577$

0.736

$\begin{array}{lll}0.819 & 0.822 & 0.698\end{array}$

0.852

0.743

$0.866 \quad 0.564$

0.807

0.749

0.693

0.758

\subsection{Structural model}

The important criteria for evaluating the PLS-SEM structural model are the significance of the path coefficients, the level of the $R^{2}$ values and the $f^{2}$ effect size. Using the PLS algorithm to access the collinearity, each predictor construct's inner VIF is below 5.0, not indicating significant collinearity issues. Coefficient of determination $\left(R^{2}\right.$ value) of each endogenous latent variable was checked. The $R^{2}$ values of customer affective commitment (0.628), customer-perceived corporate reputation (0.642) and customer loyalty (0.724) are moderate because the values are between 0.50 and 0.75 (Hair et al., 2017; Henseler et al., 2009), except for customer social benevolence trust having a slightly low value of 0.331 . The effect sizes $f^{2}$ for structural model path relationships were checked. The $f^{2}$ evaluates an exogenous construct's contribution to an endogenous variable's $R^{2}$ value. Customer awareness of corporate philanthropic activities has a low effect size of 0.098 on explaining customer-perceived 
corporate reputation's $R^{2}$ and of 0.017 on explaining affective commitment's $R^{2}$, but has a high effect size of 0.496 on explaining customer social benevolence trust (above the high threshold value of 0.35 ).

The path coefficients obtained from the PLS algorithm reflect the relative importance of the exogenous variables to the endogenous variables. We used the bootstrap approach to assess path coefficients' significance. Table 4 presents the test results of the structural model path coefficients from 500 bootstrapping subsamples. From the results, we find that the positive impact of customer awareness of corporate philanthropic activities on customer social benevolence trust $(\beta=0.576, p<0.01)$ is greater than its positive impact on customerperceived corporate reputation $(\beta=0.229, p<0.01)$ and customer affective commitment $(\beta=0.102, p<0.10)$. Customer social benevolence trust has positive greater impact on customer-perceived corporate reputation $(\beta=0.647, p<0.01)$ than its positive impact on customer affective commitment $(\beta=0.253, p<0.01)$. Customer-perceived corporate reputation has a positive impact on customer affective commitment $(\beta=0.510, p<0.01)$. The customer social benevolence trust $(\beta=0.320, p<0.01)$, affective commitment $(\beta=0.324$, $p<0.01)$ and perceived corporate reputation $(\beta=0.287, p<0.01)$ positively relate to the customer loyalty. Therefore, H1 to H9 were supported by the results.

Table 5 presents all specific indirect effects in the model (Figure 1). From the results, we can find the significant positive mediating effects of customer social benevolence trust, customer-perceived corporate reputation and affective commitment on the relationship between customer awareness of corporate philanthropic activities and customer loyalty. Especially, customer social benevolence trust plays a strong mediating role in the relationship between customer awareness of corporate philanthropic activities and perceived corporate reputation $(\beta=0.372, p<0.01)$.

\subsection{Multi-group analysis between the directed philanthropic group and general philanthropic group}

To compare the path coefficient differences between the directed philanthropic and general philanthropy group, we ran the multiple group analysis under the PLS-SEM. Table 6 presents the estimation results. From the results, we find there was no significant path coefficient difference between the two groups in our proposed model, except for the path from

\begin{tabular}{|c|c|c|c|}
\hline & $\begin{array}{l}\text { Path } \\
\text { coefficient }\end{array}$ & $t$-value & $p$-value \\
\hline $\begin{array}{l}\text { Customer awareness of corporate philanthropic activities } \rightarrow \text { customer social } \\
\text { benevolence trust (H1) }\end{array}$ & $0.576^{* * * *}$ & 7.320 & 0.000 \\
\hline $\begin{array}{l}\text { Customer awareness of corporate philanthropic activities } \rightarrow \text { customer- } \\
\text { perceived corporate reputation (H2) }\end{array}$ & $0.229 * * *$ & 3.953 & 0.000 \\
\hline $\begin{array}{l}\text { Customer social benevolence trust } \rightarrow \text { customer-perceived corporate } \\
\text { reputation (H3) }\end{array}$ & $0.647 * * *$ & 11.525 & 0.000 \\
\hline $\begin{array}{l}\text { Customer awareness of corporate philanthropic activities } \rightarrow \text { customer } \\
\text { affective commitment (H4) }\end{array}$ & $0.102^{*}$ & 1.729 & 0.086 \\
\hline Customer social benevolence trust $\rightarrow$ customer affective commitment (H5) & $0.253 * * * *$ & 3.006 & 0.003 \\
\hline $\begin{array}{l}\text { Customer-perceived corporate reputation } \rightarrow \text { customer affective } \\
\text { commitment (H6) }\end{array}$ & 0.510 **** & 5.926 & 0.000 \\
\hline Customer social benevolence trust $\rightarrow$ customer loyalty (H7) & $0.320^{* * * *}$ & 3.766 & 0.000 \\
\hline Customer affective commitment $\rightarrow$ customer loyalty (H8) & $0.324 * * *$ & 4.667 & 0.000 \\
\hline Customer-perceived corporate reputation $\rightarrow$ customer loyalty (H9) & $0.287 * * * *$ & 3.251 & 0.001 \\
\hline
\end{tabular}

Note(s): ***sig at $0.01, *$ sig at 0.10
Restaurant proactive philanthropic activities

271
Table 4. Significance testing results of the direct structural model path coefficients 


\begin{tabular}{|c|c|c|c|c|}
\hline \multirow{6}{*}{$\begin{array}{l}\mathrm{IHR} \\
35,2\end{array}$} & & Path coefficient & $t$-value & $p$-value \\
\hline & $\mathrm{cp} \rightarrow \mathrm{rep} \rightarrow \mathrm{ac}$ & $0.117 * * *$ & 3.272 & 0.001 \\
\hline & trust $\rightarrow$ rep $\rightarrow$ ac & $0.330 * * * *$ & 5.354 & 0.000 \\
\hline & $\mathrm{cp} \rightarrow$ trust $\rightarrow \mathrm{rep} \rightarrow \mathrm{ac}$ & $0.190 * * *$ & 4.894 & 0.000 \\
\hline & $\mathrm{cp} \rightarrow$ trust $\rightarrow \mathrm{ac}$ & $0.146^{* * * *}$ & 2.825 & 0.005 \\
\hline & $\mathrm{cp} \rightarrow \mathrm{ac} \rightarrow$ loyalty & $0.033^{*}$ & 1.655 & 0.099 \\
\hline \multirow[t]{10}{*}{272} & $\mathrm{cp} \rightarrow \mathrm{rep} \rightarrow \mathrm{ac} \rightarrow$ loyalty & $0.038^{* * * *}$ & 2.687 & 0.007 \\
\hline & rep $\rightarrow$ ac $\rightarrow$ loyalty & $0.165^{* * * *}$ & 3.959 & 0.000 \\
\hline & trust $\rightarrow$ rep $\rightarrow$ ac $\rightarrow$ loyalty & $0.107 * * *$ & 3.958 & 0.000 \\
\hline & $\mathrm{cp} \rightarrow$ trust $\rightarrow$ rep $\rightarrow \mathrm{ac} \rightarrow$ loyalty & $0.062 * * *$ & 3.581 & 0.000 \\
\hline & trust $\rightarrow \mathrm{ac} \rightarrow$ loyalty & $0.082 * *$ & 2.355 & 0.019 \\
\hline & $\mathrm{cp} \rightarrow$ trust $\rightarrow \mathrm{ac} \rightarrow$ loyalty & $0.047 * *$ & 2.208 & 0.028 \\
\hline & $\mathrm{cp} \rightarrow$ rep $\rightarrow$ loyalty & $0.066^{* *}$ & 2.570 & 0.010 \\
\hline & trust $\rightarrow$ rep $\rightarrow$ loyalty & $0.186^{* * * *}$ & 3.244 & 0.001 \\
\hline & $\mathrm{cp} \rightarrow$ trust $\rightarrow$ rep $\rightarrow$ loyalty & $0.107 * * * *$ & 3.013 & 0.003 \\
\hline & $\mathrm{cp} \rightarrow$ trust $\rightarrow$ loyalty & $0.184 * * *$ & 3.406 & 0.001 \\
\hline & $\mathrm{cp} \rightarrow$ trust $\rightarrow$ rep & $0.372 * * *$ & 7.913 & 0.000 \\
\hline
\end{tabular}

Significance testing results of the specific indirect effects
Note(s): cp: customer awareness of corporate philanthropic activities; trust: customer social benevolence trust; rep: customer-perceived corporate reputation; ac: customer affective commitment; loyalty: customer loyalty $* * *$ sig at $0.01, * *$ sig at $0.05, *$ sig at 0.10
Table 6.

Significance testing results of multiple group analysis

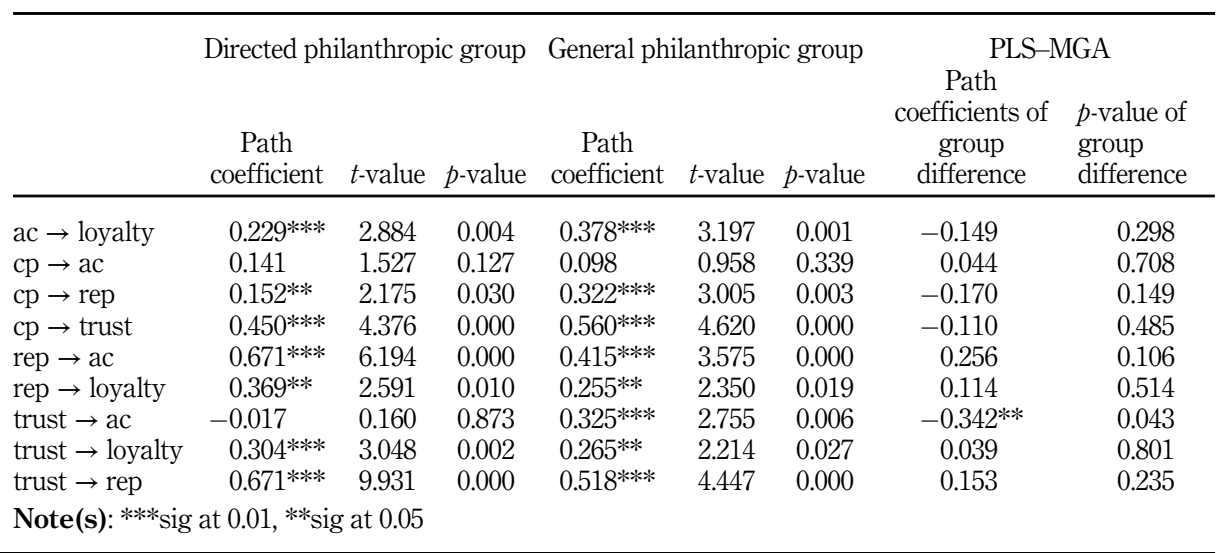

customer social benevolence trust to affective commitment $(\beta=-0.342, p<0.05)$. However, when we checked this path coefficient from the directed philanthropic group, there was no significant relationship between the social benevolence trust and affective commitment $(\beta=-0.017, p=0.873)$. Therefore, it is meaningless to conclude the significant path coefficient difference in this relationship.

\section{Discussion and conclusions}

Under the context background of the COVID-19 pandemic, this study discussed how philanthropic activities enhance customer loyalty toward the restaurant business. The study used scenarios to create the directed and general philanthropic activities from a hypothetical restaurant business and assessed respondents' awareness of these philanthropic activities and the perceptions toward social benevolence trust, corporate reputation and affective 
commitment about this hypothetical restaurant induced from the given philanthropic activities, and finally reached the loyalty toward the restaurant.

By comparing the mean value of each construct between the treatment and control group using the independent sample $t$-test, we find the mean values from the treatment group had significant differences from the control group. That means the stimulus scenarios we designed well reached the characteristics of both directed and general philanthropic activities. The respondents could be aware of the significance of these activities. Moreover, the awareness of the restaurant's philanthropic activities in the two treatment groups also had a significant mean difference. That means the respondents had a stronger awareness of restaurant directed philanthropic activity, which was working with its chefs, cooks, wait staff and the local farmers to produce, donate and deliver thousands of dollars' worth of free food (a value of US\$50,000) to the residents in the local community who are experiencing a foodinsecure situation during the COVID-19 pandemic. As the data were combined from the target and non-target sample groups, we may conclude that the directed philanthropic activities related to the pandemic context could create a greater customer awareness compared with the regular general philanthropic activities, such as donating the same amount of money to a non-profit charitable organization. In addition, the mean values of customer social benevolence trust, perceived corporate restaurant, affective attachment and customer loyalty were higher in the directed philanthropic group. This means, averagely, that the restaurant that donated free food to the local community could receive greater customer social benevolence trust, reputation and affective commitment than the restaurant that made general donations to the non-profit organization during the COVID-19 pandemic period. Customer loyalty toward the restaurant with free food donations was higher than toward the restaurant with general donations.

We set up the conceptual model and used PLS-SEM to examine the significance of the path coefficients. Our proposed $\mathrm{H} 1$ to $\mathrm{H} 9$ were supported by the estimation results. When we ran the PLS-SEM to test the hypotheses, we combined two treatment groups' data and focused on the impact of the restaurant's overall proactive philanthropic activities on customer perceptions. As we investigated the significant direct paths, when customers were aware of greater philanthropic activities and efforts proactively devoted by the restaurant, they would generate social benevolence trust toward this restaurant, believe the restaurant considering their welfare and interest and have greater confidence about this restaurant. Moreover, the created social benevolence trust would enhance customers' perception toward the restaurant's reputation and build their affective commitment with the restaurant. However, although the direct path from the customer awareness of proactive philanthropic activities to their affective commitment was significant, the direct impact of philanthropic activities was not as strong as its impact on customer social benevolence trust. That means it is more difficult for the restaurant to build an affective attachment with the customers through proactive philanthropic activities during the COVID-19 pandemic period.

Besides the direct path strengths, we also investigate the indirect path strengths to demonstrate the mediating effects of customer social benevolence trust, perceived restaurant reputation and affective commitment on the relationship between the customer philanthropic awareness and customer loyalty toward the restaurant. As the only mediator between customer philanthropic awareness and customer loyalty, the mediating effect of social benevolence trust $(\beta=0.184, p<0.01)$ is stronger than the mediating effect of perceived reputation $(\beta=0.066, p<0.05)$. The mediating effect of affective commitment is weak $(\beta=0.033, p<0.10)$.

We also examined the path strength difference between the directed philanthropic group and the general philanthropic group but did not find a significant difference. That means although we could identify the significant mean difference of each construct between these two groups, the pattern of how customer awareness of corporate philanthropic activities 
IHR

35,2

affects the customer perception toward the restaurant had no significant difference between the restaurant donating free food to the local community and the restaurant donating money to the non-profit charitable organization during the COVID-19 pandemic period.

\subsection{Theoretical implications}

This study investigated the important role of corporate philanthropy as a marketing tool to build customer loyalty in the restaurant industry. Based on Wang et al. (2019), there is a significant lack of empirical discussion regarding the impact of corporate philanthropy on key stakeholders (i.e. customers) in the hospitality field. First, considering the complexity of the concept of CSR, corporate philanthropic activities were discussed and examined as one of the dimensions of the CSR construct (Ding et al., 2018). The current study specified the unique characteristics of corporate philanthropy and distinguished the corporate philanthropic activities from other CSR dimensions, such as environmental initiatives, employee rights and corporate governance in the restaurant industry. It allowed the current study to employ scenarios to reach customer awareness and perceptions toward the restaurant's philanthropic activities. The proposed conceptual model emphasized the importance of restaurant philanthropic activities on sustaining customer loyalty during the COVID-19 pandemic period. Second, similarly to the literature on CSR, the majority of previous studies focused on whether and how corporate philanthropic activities can improve the firm's financial performance. The conclusions from the previous corporate philanthropy studies are similar to the financial impacts of conducing CSR activities, which are unclear.

The relationship between corporate philanthropy and financial performance can be positive, negative or not definitive. Rather than discussing its impact on financial performance, the current study focused on the effect of restaurant philanthropic activities on cause-related marketing. Further, it explored the direct relationship between customer awareness of restaurant philanthropy and customer loyalty and the mediating roles of strengthening customer social benevolence trust, perceived restaurant reputation and affective commitment. The proposed conceptual framework and the estimation results indicated the restaurant's philanthropic activities during the COVID-19 pandemic period can be an effective marketing tool to build strong customer trust and the affective attachment toward the restaurant and enhance restaurant reputation and customer loyalty. Third, this study used the scenario-based method to reach two different types of restaurant philanthropic activities: directed philanthropic activity and general philanthropic activity. Both types are under the proactive strategic corporate philanthropy category and reflect the restaurant's proactive marketing efforts to enhance the business image and build strong brand associations with customers during the COVID-19 pandemic period. The directed philanthropic activities show greater customer awareness and perceptions compared with the general philanthropic activity during the COVID-19 pandemic.

\subsection{Practical implications}

The current study generates several practical implications for restaurant owners and operators under the COVID-19 pandemic period. First, the current study and its results concluded the benefits of conducting corporate philanthropic activities in the restaurant business during this period. There has been a long-term debate regarding the advantages and disadvantages of corporate philanthropy. Porter and Kramer (2002) also mentioned the declining trend of donating businesses in the USA. Although most business decision-makers understand the altruism characteristic of corporate philanthropy that benefits society, conducing corporate philanthropic activities requires the firm to have a sufficient financial budget to fulfill the charitable donation needs. However, based on the resource-based view, firm resources are limited, and shareholders will more likely require higher financial returns 
from limited resources. Therefore, firm decision-makers have to choose to use the budget to create tangible value, such as investing in technologies and talents, training or donating to charities.

Restaurant businesses may especially suffer from tight budgets during the COVID-19 pandemic period and the post-COVID-19 recovery period. The current study investigated proactive corporate philanthropic activities of the restaurant as an efficient marketing tool to re-build customer loyalty during and after the pandemic period. During the recovery period, it may not be the best time to expand the restaurant business by increasing the number of properties or investing in heavy tangible assets. The priority of the restaurant business is to retain customers and attract customers back to the business. Therefore, investing in efficient marketing tools, such as corporate philanthropic activities, is important to sustain the business and its customers.

Second, the current study finds that although directed restaurant philanthropic activity, such as donating free food to the local communities, reaches higher levels of customer awareness and perceptions compared with general donations, the effects of these two types of philanthropy on customer loyalty are not significantly different. Directed free food donations are the short-term philanthropic activities of restaurants during the COVID-19 period. Not all restaurants made such donations. As the industry moves forward to the post-COVID-19 pandemic period, the study results suggested that the restaurant with and without directed free food donations during the previous months in 2020 may consider using corporate philanthropy as a marketing tool in the long run. The proactive general philanthropic activities can also help the restaurant rebuild customer trust, corporate reputation, affective attachment and further customer loyalty. Third, the current study not only points out the importance of proactive corporate philanthropy but also emphasizes the importance of the different customer awareness of the two types of restaurant philanthropic activities. In our scenarios, the restaurant donated the same amount of value to the directed and general philanthropic activities and the same social media reported to customers. However, customer awareness of the directed philanthropic activities is significantly greater than the general philanthropic activity. This indicated that customers more easily realize the restaurant's efforts from the directed philanthropic activities based on the same financial budget. As customer awareness is an important predictor of customer loyalty, restaurant decisionmakers may consider using directed philanthropic strategies to reach efficient marketing outcomes.

\subsection{Limitations and suggestions for future research}

This study is a pioneering work to explore the empirical evidence of the impact of customer awareness of corporate philanthropy on customer loyalty in the restaurant industry under the COVID-19 pandemic period. However, this study also has a few limitations that may be improved in future studies. First, this study combined the target and non-target samples to reach the overall proactive corporate philanthropic activities. Based on the literature, the respondents from the target population and the non-target population may have different awareness and perceptions toward each type of corporate philanthropic activity. Future studies will further discuss the differences between the target and non-target samples. Last, but not least, further study may use any ex ante procedural remedies to reduce the bias of the CMV. The possible procedural remedies such as the temporal separation method may be used during the research design and data collection process. The data of independent variables and dependent variables in the model related to customers' perceptions can be collected by two surveys with a reasonable time interval (two-wave) rather than a single point in time (Min et al., 2016). This procedural remedy will further reduce CMV. 
IHR

35,2

\section{References}

Aaker, D. (1991), Managing Brand Equity. Capitalizing on the Value of a Brand Name, The Free Press, New York, NY.

Abratt, R. and Kleyn, N. (2012), "Corporate identity, corporate branding and corporate reputations: reconciliation and integration", European Journal of Marketing, Vol. 46 Nos 7/8, pp. 1048-1063.

Ali, F., Kim, W.G., Li, J.J. and Cobanoglu, C. (2018), "A comparative study of covariance and partial least squares based structural equation modelling in hospitality and tourism research", International Journal of Contemporary Hospitality Management, Vol. 30 No. 1, pp. 416-435.

Ali, F., Ciftci, O., Nanu, L., Cobanoglu, C. and Ryu, K. (2020), "Response rates in hospitality research: an overview of current practice and suggestions for future research", Cornell Hospitality Quarterly, Vol. 62 No. 1, pp. 105-120.

Allen, N.J. and Meyer, J.P. (1990), "The measurement and antecedents of affective, continuance and normative commitment to the organization", Journal of Occupational and Organizational Psychology, Vol. 63 No. 1, pp. 1-18.

Alniacik, U., Cigerim, E., Akcin, K. and Bayram, O. (2011), "Independent and joint effects of perceived corporate reputation, affective commitment and job satisfaction on turnover intentions", Procedia Social and Behavioral Sciences, Vol. 24, pp. 1177-1189.

Ashforth, B.E. and Mael, F. (1989), "Social identity theory and the organization", Academy of Management Review, Vol. 14 No. 1, pp. 20-39.

Bansal, H.S., Irving, P.G. and Taylor, S.F. (2004), "A three-component model of customer commitment to service providers", Journal of the Academy of Marketing Science, Vol. 32 No. 3, pp. 234-250.

Barnett, M.L., Jermier, J.M. and Lafferty, B.A. (2006), "Corporate reputation: the definitional landscape”, Corporate Reputation Review, Vol. 9 No. 1, pp. 26-38.

Bartikowski, B. and Walsh, G. (2011), "Investigating mediators between corporate reputation and customer citizenship behaviors", Journal of Business Research, Vol. 64 No. 1, pp. 39-44.

Behrend, T.S., Sharek, D.J., Meade, A.W. and Wiebe, E.N. (2011), "The viability of crowdsourcing for survey research", Behavior Research Methods, Vol. 43 No. 3, pp. 800-813.

Bramner, S. and Millington, A. (2005), "Corporate reputation and philanthropy: an empirical analysis", Journal of Business Ethics, Vol. 61 No. 1, pp. 29-44.

Brown, T.J., Dacin, P.A., Pratt, M.G. and Whetten, D.A. (2006), "Identity, intended image, construed image, and reputation: an interdisciplinary framework and suggested terminology", Journal of the Academy of Marketing Science, Vol. 34 No. 2, pp. 99-106.

Carroll, A.B. and Shabana, K.M. (2010), "The business case for corporate social responsibility: a review of concepts, research and practice", International Journal of Management Reviews, Vol. 12 No. 1, pp. 85-105.

Casalo, L.V., Flavian, C. and Guinalíu, M. (2007), "The influence of satisfaction, perceived reputation and trust on a consumer's commitment to a website", Journal of Marketing Communications, Vol. 13 No. 1, pp. 1-17.

CDC (2020), “CDC COVID data tracker”, available at: https://covid.cdc.gov/covid-data-tracker/\#cases_ casesper100klast7days (accessed 31 December 2020).

Choi, B. and La, S. (2013), "The impact of corporate social responsibility (CSR) and customer trust on the restoration of loyalty after service failure and recovery", Journal of Services Marketing, Vol. 27 No. 3, pp. 223-233.

Clifford, L., Wahba, P. and Fortune Editor (2020), "A running list of companies that have filed for bankruptcy during the coronavirus pandemic", available at: https:/fortune.com/2020/08/04/ companies-filing-bankruptcy-2020-due-to-covid-list-filed-chapter-11-coronavirus-pandemic/ (accessed 26 August 2020). 
Cronin, J.J., Brady, M.K. and Hult, G. (2000), "Assessing the effects of quality, value, and customer satisfaction on consumer behavioral intentions in service environments", Journal of Retailing, Vol. 76 No. 2, pp. 193-218.

Ding, L., Yang, J. and Chung, Y. (2018), "Effects of corporate social performance on corporate financial performance: a two-sector analysis between the US hospitality and manufacturing companies", Global Business and Finance Review, Vol. 23 No. 1, pp. 1-16.

DOL (2020), "The employment situation-July 2020", available at: https://www.bls.gov/news.release/ pdf/empsit.pdf (accessed 26 August 2020).

Dowling, G. (2006), "How good corporate reputations create corporate value", Corporate Reputation Review, Vol. 9 No. 2, pp. 134-143.

Fishbein, M. and Ajzen, I. (1975), Belief, Attitude, Intention, and Behavior: An Introduction to Theory and Research, Addison-Wesley, Reading, MA.

Friedman, M. (1970), "The social responsibility of business is to increase its profits”, New York Times Magazine, September 13, pp. 122-126.

Fry, L.W., Keim, G.D. and Meiners, R.E. (1982), "Corporate contributions: altruistic or for profit", Academy of Management Journal, Vol. 25 No. 1, pp. 94-106.

Fullerton, G. (2003), “When does commitment lead to loyalty?", Journal of Service Research, Vol. 5 No. 4, pp. 333-344.

Fullerton, G. (2011), "Creating advocates: the roles of satisfaction, trust and commitment", Journal of Retailing and Consumer Services, Vol. 18 No. 1, pp. 92-100.

Glavas, A. and Godwin, L.N. (2013), "Is the perception of 'goodness' good enough? Exploring the relationship between perceived corporate social responsibility and employee organizational identification”, Journal of Business Ethics, Vol. 114 No. 1, pp. 15-27.

Godfrey, P.C. (2005), "The relationship between corporate philanthropy and share-holder wealth: a risk management perspective", Academy of Management Review, Vol. 30 No. 4, pp. 777-798.

Gozukara, I. and Yildirim, O. (2015), "Affective commitment and corporate reputation. The effects of attitude toward advertising and trust", Academic Journal of Economic Studies, Vol. 1 No. 3, pp. 126-147.

Gronholdt, L., Martensen, A. and Kristensen, K. (2000), "The relationship between customer satisfaction and loyalty: cross-industry differences", Total Quality Management, Vol. 11 Nos 4/5/6, pp. 509-514.

Hair, J.F., Ringle, C.M. and Sarstedt, M. (2011), "PLS-SEM: indeed a silver bullet", Journal of Marketing Theory and Practice, Vol. 18 No. 2, pp. 139-152.

Hair, J.F. Jr, Hult, G.T.M., Ringle, C. and Sarstedt, M. (2017), A Primer on Partial Least Squares Structural Equation Modeling (PLS-SEM), Sage publications, Thousand Oaks, CA.

Henseler, J., Ringle, C.M. and Sinkovics, R.R. (2009), "The use of partial least squares path modeling in international marketing", Advances in International Marketing, Vol. 8 No. 20, pp. 277-319.

Hur, W.M., Kim, H. and Woo, J. (2014), "How CSR leads to corporate brand equity: mediating mechanisms of corporate brand credibility and reputation”, Journal of Business Ethics, Vol. 125 No. 1, pp. 75-86.

Hur, W.M., Kim, H. and Kim, H.K. (2018), "Does customer engagement in corporate social responsibility initiatives lead to customer citizenship behaviour? The mediating roles of customer-company identification and affective commitment", Corporate Social Responsibility and Environmental Management, Vol. 25 No. 6, pp. 1258-1269.

Iglesias, O., Markovic, S. and Rialp, J. (2019), "How does sensory brand experience influence brand equity? Considering the roles of customer satisfaction, customer affective commitment, and employee empathy", Journal of Business Research, Vol. 96, pp. 343-354.

Jalilvand, M.R., Vosta, L.N., Mahyari, H.K. and Pool, J.K. (2017), "Social responsibility influence on customer trust in hotels: mediating effects of reputation and word-of-mouth", Tourism Review, Vol. 72 No. 1, pp. 1-14. 
IHR

35,2

Keh, H.T. and Xie, Y. (2009), "Corporate reputation and customer behavioral intentions: the roles of trust, identification and commitment", Industrial Marketing Management, Vol. 38 No. 7, pp. $732-742$.

Kim, S.B. and Kim, D.Y. (2016), "The impacts of corporate social responsibility, service quality, and transparency on relationship quality and customer loyalty in the hotel industry", Asian Journal of Sustainability and Social Responsibility, Vol. 1 No. 1, pp. 39-55.

Kim, W.G., Lee, S. and Lee, H.Y. (2007), "Co-branding and brand loyalty”, Journal of Quality Assurance in Hospitality and Tourism, Vol. 8 No. 2, pp. 1-23.

Lee, Y.K., Choi, J., Moon, B.Y. and Babin, B.J. (2014), "Codes of ethics, corporate philanthropy, and employee responses", International Journal of Hospitality Management, Vol. 39, pp. 97-106.

Lim, T. (2010), "Measuring the value of corporate philanthropy: social impact, business benefits, and investor returns", available at: http://cecp.co/pdfs/resources/MVCP_report_singles.pdf (accessed 26 August 2020).

MacKenzie, S.B. and Podsakoff, P.M. (2012), "Common method bias in marketing: causes, mechanisms, and procedural remedies", Journal of Retailing, Vol. 88 No. 4, pp. 542-555.

Markovic, S., Iglesias, O., Singh, J.J. and Sierra, V. (2018), "How does the perceived ethicality of corporate services brands influence loyalty and positive word-of-mouth? Analyzing the roles of empathy, affective commitment, and perceived quality", Journal of Business Ethics, Vol. 148 No. 4, pp. 721-740.

Martínez, P. and Del Bosque, I.R. (2013), "CSR and customer loyalty: the roles of trust, customer identification with the company and satisfaction", International Journal of Hospitality Management, Vol. 35, pp. 89-99.

Mattila, A.S. (2006), "How affective commitment boosts guest loyalty (and promotes frequent-guest programs)", Cornell Hotel and Restaurant Administration Quarterly, Vol. 47 No. 2, pp. 174-181.

Maze, J. (2020), "Restaurants are giving away a lot of meals", available at: https://www. restaurantbusinessonline.com/marketing/restaurants-are-giving-away-lot-meals (accessed 26 August 2020).

Min, H., Park, J. and Kim, H.J. (2016), "Common method bias in hospitality research: a critical review of literature and an empirical study", International Journal of Hospitality Management, Vol. 56, pp. 126-135.

Morgan, R.M. and Hunt, S.D. (1994), "The commitment-trust theory of relationship marketing”, Journal of Marketing, Vol. 58 No. 3, pp. 20-38.

Namkung, Y. and Jang, S. (2007), "Does food quality really matter in restaurants? Its impact on customer satisfaction and behavioral intentions", Journal of Hospitality and Tourism Research, Vol. 31 No. 3, pp. 387-409.

National Restaurant Associations (2020), "Restaurant sales fell to their lowest real level in over 35 years", available at: https://restaurant.org/articles/news/restaurant-sales-fell-to-lowest-level-in35-years (accessed 26 August 2020).

Nierenberg, J. (2020), "30+Restaurants giving back to their communities with free meals and groceries during COVID019", available at: https://foodtank.com/news/2020/04/23-restaurants-givingback-to-their-communities-with-free-meals-and-groceries-during-covid-19-2/ (accessed 26 August 2020).

Park, J., Lee, H. and Kim, C. (2014), "Corporate social responsibilities, consumer trust and corporate reputation: South Korean consumers' perspectives”, Journal of Business Research, Vol. 67 No. 3, pp. 295-302.

Peterson, D.K. (2018), "Enhancing corporate reputation through corporate philanthropy", Journal of Strategy and Management, Vol. 11 No. 1, pp. 18-32.

Podsakoff, P.M., MacKenzie, S.B., Lee, J.Y. and Podsakoff, N.P. (2003), "Common method biases in behavioral research: a critical review of the literature and recommended remedies", Journal of Applied Psychology, Vol. 88 No. 5, pp. 879-903. 
Podsakoff, P.M., MacKenzie, S.B. and Podsakoff, N.P. (2012), "Sources of method bias in social science research and recommendations on how to control it", Annual Review of Psychology, Vol. 63, pp. 539-569.

Porter, M.E. and Kramer, M.R. (2002), "The competitive advantage of corporate philanthropy", Harvard Business Review, Vol. 80 No. 12, pp. 56-68.

Restaurant proactive philanthropic activities

Ricks, J.M. (2005), "An assessment of strategic corporate philanthropy on perceptions of brand equity variables", Journal of Consumer Marketing, Vol. 22 No. 3, pp. 121-134.

Servaes, H. and Tamayo, A. (2013), "The impact of corporate social responsibility on firm value: the role of customer awareness", Management Science, Vol. 59 No. 5, pp. 1045-1061.

Smart, K., Ma, E., Qu, H. and Ding, L. (2021), "COVID-19 impacts, coping strategies, and management reflection: a lodging industry case", International Journal of Hospitality Management, Vol. 94, 102859 .

Szőcs, I., Schlegelmilch, B.B., Rusch, T. and Shamma, H.M. (2016), "Linking cause assessment, corporate philanthropy, and corporate reputation", Journal of the Academy of Marketing Science, Vol. 44 No. 3, pp. 376-396.

Tajfel, H. and Turner, J. (1985), "The social identity theory of intergroup behavior”, in Worchel, S. and Austin, W. (Eds), Psychology of Intergroup Relations, Nelson Hall, Chicago, IL, pp. 7-24.

Walker, M. and Kent, A. (2013), "The roles of credibility and social consciousness in the corporate philanthropy-consumer behavior relationship", Journal of Business Ethics, Vol. 116 No. 2, pp. 341-353.

Wang, H., Choi, J. and Li, J. (2008), "Too little or too much? Untangling the relationship between corporate philanthropy and firm financial performance", Organization Science, Vol. 19 No. 1, pp. 143-159.

Wang, K., Chen, M.H., Lin, C.P. and Hu, D.F. (2019), "Corporate philanthropy effect on hospitality consumer benefit", Journal of Hospitality and Tourism Management, Vol. 39, pp. 224-227.

WHO (2020), "WHO coronavirus disease (COVID-19) dashboard", available at: https://covid19.who.int/ (accessed 1 January 2021).

Xie, Y. and Peng, S. (2011), "How do corporate associations influence customer relationship strength? The effects of different types of trust", Journal of Strategic Marketing, Vol. 19 No. 5, pp. 443-454.

\begin{abstract}
About the authors
Dr Li Ding is an Assistant Professor at the Institut Paul Bocuse, France. Dr. Ding graduated from Oklahoma State University in 2018 with a doctoral degree in Hospitality Management. Dr. Ding's research concentrates on financial management and strategic management. Li Ding is the corresponding author and can be contacted at: li.ding@institutpaulbocuse.com

Dr Caifen Jiang is an Associate Professor in the School of Management at Guangzhou University, China. Dr. Jiang's research concentrates on consumer behavior and marketing.
\end{abstract}

For instructions on how to order reprints of this article, please visit our website:

www.emeraldgrouppublishing.com/licensing/reprints.htm

Or contact us for further details: permissions@emeraldinsight.com 